\title{
SEGMENTASI PASAR PENYEDIA JASA LOGISTIK (THIRD PARTY LOGISTICS) DI INDONESIA
}

\author{
Darjat Sudrajat \\ Jurusan Manajemen, Fakultas Ekonomi dan Bisnis, Universitas Bina Nusantara \\ Jln. K.H. Syahdan No. 9, Palmerah, Jakarta Barat 11480 \\ sudrajatd@binus.ac.id
}

\begin{abstract}
Market segmentation is fundamental in marketing strategy and the first step of market-based strategy preparation, to strengthen its marketing efficiency, and creating opportunities for sales growth and profits. This also applies to market segmentation logistics service providers (TPL - Third Party Logistics), the market is highly developed in the last decade, so that the logistics service providers has to develop marketing strategies properly. The purpose of this research is to gain a better understanding of different industries that exist today and map the needs of the logistics services of TPL customers. Based on exploration research conducted, it can be found in conformities relating to the logistics industry from several companies, ie appropriateness to the complexity of logistics activities of some companies and degree of investment of TPL services company in conducting the activity. Logistics service provider market segmentation can be based on variable complexity of logistics activities, whether it is high, medium or low and variable degrees of investment in the company whether minor, major, or integrated/total. Companies in different industries can have the same logistic service requirements and companies in the same industry can have different logistic service requirements. Client companies for logistics service providers which product handling are classified as semi-complex is the most attractive customer segments for being penetrated. The industries are classified into this segment is automotive, food and beverage, animal food, ceramic, and plantation.
\end{abstract}

Keywords: segmentation, third party logistic, logistic, outsourcing

\begin{abstract}
ABSTRAK
Segmentasi pasar adalah hal mendasar dalam strategi pemasaran dan langkah awal penyusunan strategi berbasis pasar, dapat memperkuat efisiensi pemasaran serta menciptakan peluang-peluang pertumbuhan penjualan dan keuntungan. Hal ini pun berlaku pada segmentasi pasar penyedia jasa logistik (TPL - Third Party Logistics), pasar yang sangat berkembang dalam dekade terakhir ini sehingga para penyedia jasa logistik dapat mengembangkan strategi pemasarannya dengan baik. Adapun maksud penelitian ini adalah memperoleh suatu pemahaman yang lebih baik terhadap industri-industri yang berbeda yang ada sekarang dan memetakan kebutuhan-kebutuhan jasa logistik dari pelanggan TPL. Berdasarkan riset ekplorasi yang dilakukan, maka dapat ditemukan kesesuaian-kesesuaian yang berhubungan dengan industri logistik dari beberapa perusahaan, yaitu kesesuaian pada kompleksitas aktivitas logistik dari beberapa perusahaan dan derajat penyertaan perusahaan jasa logistik pihak ketiga dalam melakukan aktivitas tersebut. Segmentasi pasar penyedia jasa logistik dapat didasarkan pada variabel kompleksitas aktivitas logistiknya yaitu tinggi, sedang atau rendah dan variabel derajat penyertaan perusahaannya apakah minor, mayor, atau integrated/total. Perusahaan-perusahaan dalam industri yang berbeda dapat mempunyai keperluan jasa logistik yang sama dan perusahaan-peusahaan dalam industri yang sama dapat mempunyai keperluan jasa logistik yang berbeda. Perusahaan-perusahaan pelanggan penyedia jasa logistik yang penanganan produknya tergolong semi kompleks merupakan segmen pelanggan yang paling menarik untuk dipenetrasi. Industri-industri yang tergolong ke dalam segmen ini adalah otomotif, makanan dan minuman, pakan ternak, keramik, dan perkebunan.
\end{abstract}

Kata kunci: segmentasi, third party logistic, logistik, outsourcing 


\section{PENDAHULUAN}

Akhir-akhir ini, istilah outsorcing menjadi sangat populer di perusahaan-perusahaan, baik yang bergerak dalam bidang jasa maupun manufaktur. Banyak perusahaan telah menyadari perlunya memfokuskan diri pada kompetensi intinya, agar tetap dapat bersaing di pasar. Oleh karena itu, mereka menyerahkan kegiatan-kegiatan yang bukan kompetensi intinya kepada pihak ketiga (outsourcing) agar lebih dapat memfokuskan diri dalam pengembangan kompetensi intinya. Outsourcing juga telah menjadi suatu tema yang dominan dalam Supply Chain Management (SCM). Fungsi-fungsi dan kegiatan-kegiatan logistik sering menjadi bagian dari perusahaan yang pelaksanaannya diserahkan kepada pihak ketiga.

Oleh sebab itu, industri penyediaan jasa logistik (Third Party Logistics/TPL) telah berkembang sangat pesat dan diperkirakan masih akan tumbuh terus. Pada awalnya, banyak penyedia jasa logistik merupakan bagian dari perusahaan yang lebih besar, biasanya perusahaan transportasi dan pergudangan tradisional. Akhirnya, berkembang menjadi perusahaan TPL tersendiri, dengan spesialisasi pada bidang-bidang tertentu seperti IT, konsultan, dan jasa keuangan.

Sekarang, banyak perusahaan jasa logistik mengelompokkan para pelanggannya berdasarkan jenis bisnisnya, misalnya industri makanan dan minuman, kimia, tekstil dan produk tekstil, agroindustri, kimia, dan elektronik. Pengelompokan ini sangat general dan sebagian besar berdasarkan asumsi-asumsi. Para pelanggan dikelompokkan ke dalam industri-industri yang berbeda dan perusahaan-perusahaan dalam industri yang sama dianggap mempunyai kebutuhan jasa logistik yang sama, tetapi pertanyaan-pertanyaannya adalah "apakah hal ini realistis?”, “apakah industri-industri tersebut merupakan suatu divisi produk perusahaan”, "apakah pengelompokan industri ini mencerminkan kebutuhan jasa logistik mereka?, "dapatkah 2 perusahaan dalam suatu industri yang sama mempunyai kebutuhan jasa logistik yang berbeda, atau mungkinkah kedua perusahaan dari industri yang berbeda mempunyai kebutuhan jasa logistik yang sama?” serta bagaimana karakteristik dan kemenarikan dari setiap segmen yang ada?. Pertanyaan-pertanyaan tersebut merupakan permasalahan yang melatarbelakangi disusunnya penelitian ini, yang dapat dirumuskan sebagai berikut:

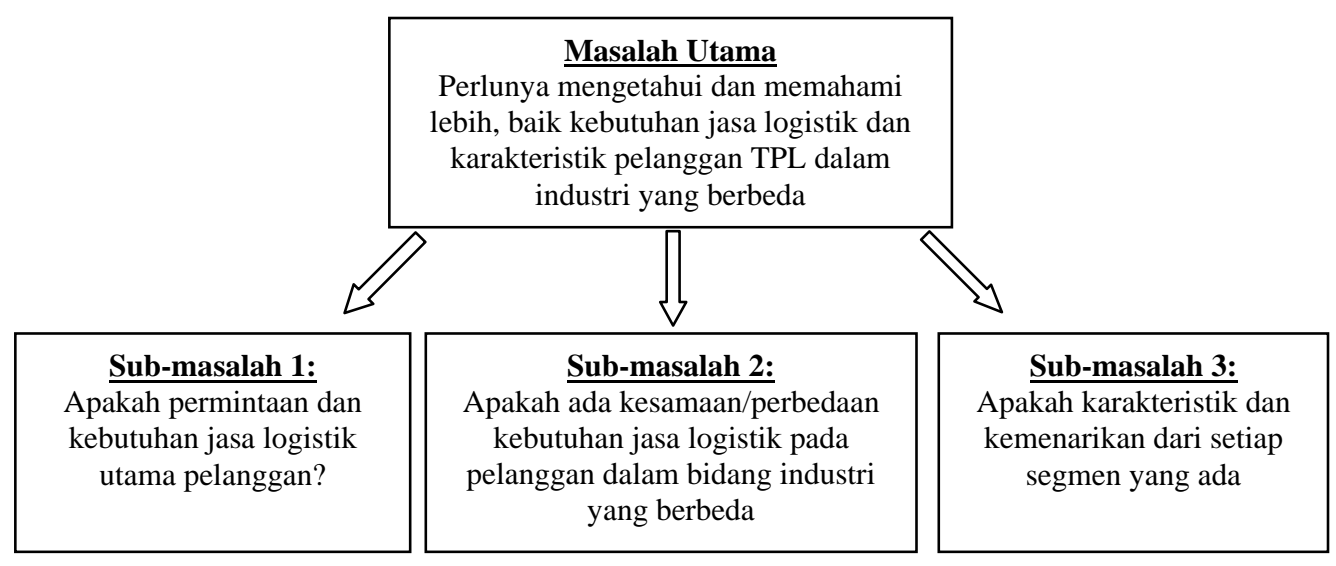

\section{Rumusan Masalah}

Definisi umum pihak ketiga (third party) adalah seseorang atau pihak sebagai pengganti 2 orang/pihak utama yang terikat dalam suatu kesepakatan, kontrak, hukum dan sebagainya, definisi ini dapat dipakai pada kasus TPL. Suatu perusahaan yang bertindak sebagai perantara antara 2 pihak 
utama dalam suatu rantai pasokan (supply chain) merupakan suatu third party. Pihak ketiga menangani aliran barang sebagai pengganti pengirim atau penerima, yang berperan sebagai pihak pertama dan kedua.

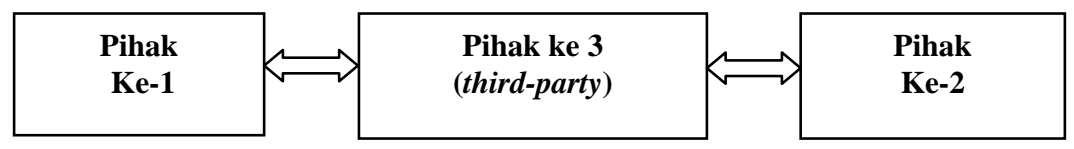

Gambar 1 Lokasi Pihak Ketiga

Menurut Simchi-Levi (2004), Third Party Logistics adalah penggunaan perusahaan pihak luar untuk melaksanakan sebagian atau seluruh fungsi manajemen material dan distribusi produk perusahaan. Logistik sendiri merupakan kegiatan yang terdiri dari aliran material pisik, aliran kas, aliran informasi, dan aliran sumber daya. Aliran material pisik dapat dibagi ke dalam 3 aliran yang berbeda, yaitu (1) Aliran utama, yang terdiri dari segala hal dari mulai bahan baku sampai produk akhir yang dibeli oleh konsumen, (2) Aliran suku cadang atau jasa setelah penjualan, dan (3) Aliran balik dari item-item yang pernah menjadi bagian dari aliran utama (misalnya produk bekas, rusak, usang, dan sebagainya). Jadi, logistik dapat dikatakan meliputi semua kegiatan yang diperlukan untuk memungkinkan perusahaan merencanakan, mengendalikan, dan melaksanakan keempat aliran yang berbeda tersebut. Menurut Stock dan Lambert (2001), manajemen logistik adalah bagian dari proses rantai pasok (supply chain) yang merencanakan, mengimplementasikan, dan mengendalikan aliran barang, jasa, dan informasi secara efektif dan efisien dari titik awal (origin) sampai akhir (konsumsi) dalam rangka memenuhi permintaan pelanggan.

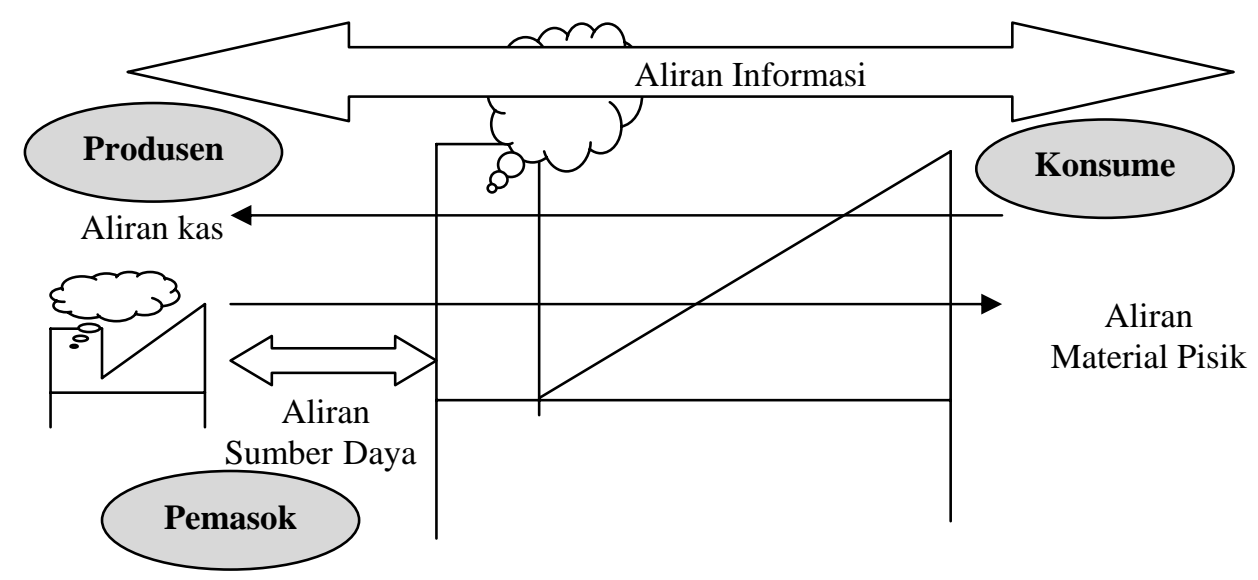

Gambar 2 Aliran Kegiatan Logistik

Bowersox (2002) secara lebih spesifik mengatakan bahwa logistik adalah kegiatan yang diperlukan untuk memindahkan dan menempatkan persediaan sepanjang rantai pasokan (supply chain), sedangkan supply chain managemet sendiri merupakan kolaborasi dari perusahaan-perusahaan yang bertujuan meningkatkan positioning strategis dan memperbaiki efisiensi operasi. Berdasarkan definisi-definisi di atas, maka fungsi logistik merupakan bagian dari fungsi supply chain, di mana suatu supply chain itu sendiri merupakan jejaring proses yang berorientasi sasaran dan titik-titik penyimpanan yang digunakan untuk menyampaikan barang dan jasa kepada pelanggan (Hopp, 2008). Sedangkan menurut Simchi-Levi (2004), supply chain management merupakan suatu pendekatan yang digunakan untuk mengintegrasikan para suplier, pabrikan, gudang, dan toko/outlet sehingga barang 
diproduksi dan didistribusikan secara tepat jumlah, tepat lokasi, dan tepat waktu dengan biaya keseluruhan seminimal mungkin, namun dapat memberikan kepusan sesuai yang diinginkan.

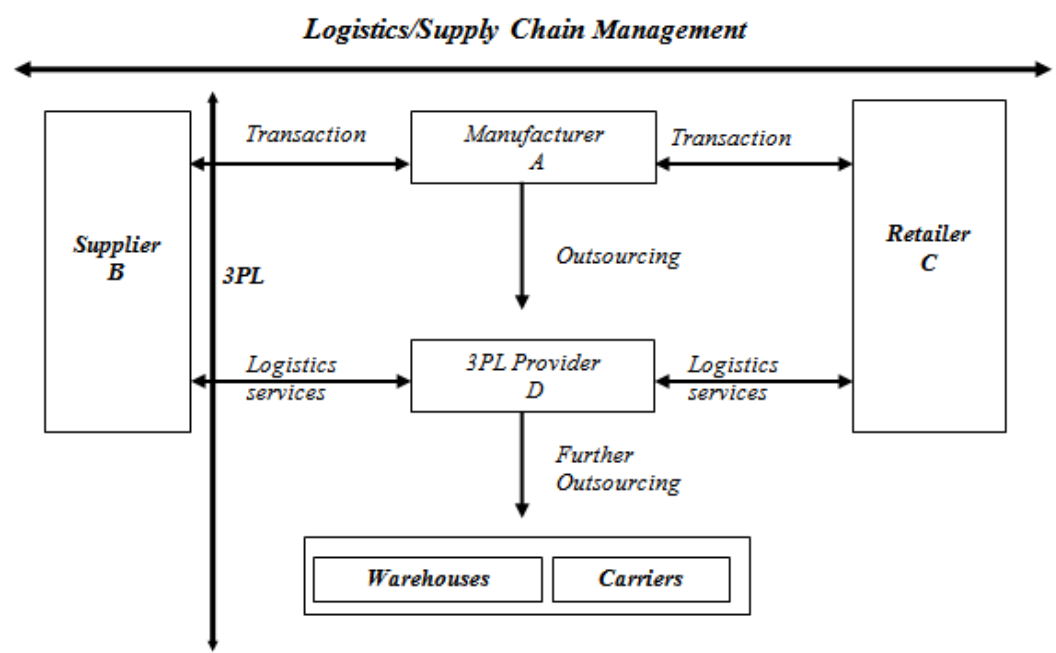

Gambar 3 Model Third Party Logistics

Adapun cakupan jasa dari Third Party Logistics meliputi (1) Transportation/distribution, yaitu general trucking service (TL, LTL), intermodal transportation service (rail, ocean, air freight), specialized services (bulk, tank, hazardous material, refrigerated goods, etc.), time-constrained services (JIT, over night, same day, etc.), dan shipment tracking \& tracing; (2) Warehousing /distribution, yaitu public/contract/regional warehouse, operation technology (bar coding, radio frequency, etc.), value-added services (cross-docking, freight consolidation, pick \& pack, etc.), dan order processing and fulfillment; (3) Customs Services, yaitu customs brokerage dan duty drawback; (4) Freight finance services, yaitu freight audit dan freight bill payment; (5) IT Support, yaitu EDI capability, logistics information system \& other softwares, dan web-based solution; (6) Product support services, yaitu reverse logistics dan value-added services (package, label, mark, test, assembly, etc.); (7) Logistics management/consulting, yaitu fleet operation, distribution network design, carrier selection/negotiation/routing, facility location analysis/selection/design, dan inventory management.

Segmentasi pasar pada dasarnya adalah proses membagi pasar keseluruhan suatu produk atau jasa yang bersifat heterogen ke dalam beberapa segmen, di mana masing-masing segmennya cenderung bersifat homogen dalam segala aspek. Menurut Cravens (2009), segmentasi pasar adalah proses penempatan para pembeli dalam suatu produk-pasar ke dalam beberapa sub grup sehingga anggota-anggota segmen memberikan respon yang sama terhadap strategi positioning tertentu. Suatu segmen pasar adalah suatu kelompok pelanggan yang spesifik dengan kebutuhan, perilaku pembelian, dan karakteristik lainnya yang unik (Best, 2004). Menurut Alsem (2007), suatu grup pelanggan dapat dikelompokkan menjadi satu segmen jika keempat kondisi berikut dipenuhi, yaitu homogeneity/ heterogeneity, sufficient size, measurable/identifiable, dan accessible. Adapun variabel-variabel segmentasi pasar dapat dikelompokkan secara umum berdasarkan background customer characteristics, customer attitudes, dan customer behavior (Hooley, 2008).

Proses yang perlu dilakukan dalam segmentasi pasar ini (Walker, 2005) adalah sebagai berikut (1) Selection of meaningful descriptors (variables) in a given market situation, (2) Determination of whether and to what extent there are differences in the dependent (outcome) variables, dan (3) Evaluation of the results step 2 to determine the effectiveness and usefulness of the segment scheme. 
Dalam situasi persaingan yang sangat tinggi saat ini, tidak banyak perusahaan yang mampu bersaing dengan mengandalkan harga semata. Di berbagai macam pasar yang ada, jarang sekali terjadi bahwa produk yang paling murah adalah yang berhasil, maka segmentasi harus dilakukan untuk dapat membedakan diri dari pesaing.

Sebenarnya tidak banyak perusahaan yang mampu menjadi segalanya bagi semua orang. Tujuan dari segmentasi pasar sebagai bagian dari perencanaan adalah untuk memungkinkan suatu perusahaan untuk mengarahkan upayanya pada peluang yang paling menjanjikan. Tetapi, suatu peluang bagi perusahaan A tidak harus menjadi peluang bagi perusahaan B. Dengan demikian, suatu perusahaan harus mengembangkan suatu tipologi pelanggan atau segmen yang dipilihnya. Yang penting dari segmentasi adalah suatu perusahaan harus melakukan salah satu dari hal-hal sebagai berikut (1) Mendefinisikan pasarnya secara cukup luas sehingga dapat memastikan bahwa biaya untuk melakukan kegiatan utama masih tetap bersaing, dan (2) Mendefinisikan pasarnya dengan cara sedemikian rupa sehingga dapat menawarkan nilai unik pada konsumennya.

Kedua tugas tersebut harus dihubungkan dengan kompetensi pembeda perusahaan dengan pesaingnya. Adapun tujuan dari segmentasi pasar adalah sebagai berikut (1) Membantu menetapkan fokus sumber daya dan upaya perusahaan yang terbaik dalam menciptakan keunggulan pembeda dan nilai bagi pelanggan, (2) Membantu menetapkan sasaran pemasaran dan penjualan yang realistis dan dapat dicapai serta (3) Memperbaiki kualitas pengambilan keputusan dengan mendorong manajer untuk mempertimbangkan pilihan-pilihan di masa yang akan datang dengan lebih mendalam.

\section{METODE PENELITIAN}

Jenis penelitian yang digunakan adalah penelitian riset, yaitu riset eksplorasi, riset yang digunakan untuk memperoleh pemahaman dan gambaran yang mendalam mengenai industri jasa logistik dan memperoleh variabel-variabel penting yang selanjutnya digunakan untuk penyusunan kuesioner. Metode riset yang digunakan untuk jenis riset ini adalah indepth interview dan desk research. Adapun data yang digunakan adalah data primer dan data sekunder. Data primer adalah data yang diperoleh dari interview, sedangkan data sekunder diperoleh melalui direktori B2B Indonesia, Kompassindo, dan data Badan Pusat Statistik (BPS) Indonesia. Jumlah sampel perusahaan yang diwawancarai adalah sebanyak 56 perusahaan. Perusahaan-perusahaan tersebut berasal dari berbagai industri dan berbagai tipe bisnis di Jakarta, Bogor, Tangerang dan Bekasi, yaitu kimia dan farmasi sebanyak 7 perusahaan, consumer goods sebanyak 5 perusahaan, makanan dan minuman sebanyak 5 perusahaan, otomotif dan sparepart sebanyak 5 perusahaan, kosmetik sebanyak 3 perusahaan, sepatu sebanyak 3 perusahaan, olahan minyak bumi sebanyak 2 perusahaan, kertas sebanyak 2 perusahaan, konstruksi sebanyak 2 perusahaan, retail sebanyak 2 perusahaan, elektronik sebanyak 1 perusahaan, garmen sebanyak 1 perusahaan, serta lainnya sebanyak 18 perusahaan.

\section{HASIL DAN PEMBAHASAN}

Sekitar 86\% dari perusahaan melakukan kegiatan impor untuk bahan baku produksi dan hampir seluruh perusahaan (95\%) memperoleh bahan bakunya dari pasar lokal. Sementara itu, 52\% dari mereka melakukan kegiatan ekspor untuk pemasaran barang jadinya, dan 91\% melakukan pemasaran lokal. Untuk melakukan aktivitas logistik, perusahaan-perusahaan tersebut menyerahkan beberapa kegiatan logistiknya pada jasa pihak ketiga atau perusahaan jasa logistik. Jasa sea freight merupakan layanan yang umumnya diserahkan pada perusahaan penyedia jasa logistik. Sekitar 93\% perusahaan pelanggan menggunakan jasa sea freight yang diserahkannya pada perusahaan penyedia 
jasa logistik. Sekitar 41\% perusahaan menggunakan layanan air freight yang ditawarkan oleh perusahaan jasa logistik. Sementara itu, hanya sekitar 3\% saja perusahaan yang menggunakan jasa trucking (dari/ke) pelabuhan yang ditawarkan perusahaan jasa logistik. Untuk trucking, sekitar 28\% perusahaan menggunakan perusahaan jasa logistik untuk pengangkutan bahan bakunya dari pemasok. Untuk distribusi, sekitar 77\% perusahaan telah menggunakan perusahaan jasa logistik.

Sementara itu, untuk aktivitas pergudangan, baru sekitar 23\% perusahaan yang telah menggunakan jasa pihak ketiga. Untuk urusan clearance, biasanya perusahaan menyerahkan pada jasa pihak ketiga (82,14\%). Sedangkan manajemen warehousing, repacking, dan labelling, sistem informasi dan tracing/tracking adalah jenis layanan yang tidak banyak dipakai oleh perusahaanperusahaan pelanggan (kurang dari 11\%). Berdasarkan analisis kualitatif, yaitu dengan melihat kesesuaian-kesesuaian yang berhubungan dengan industri logistik dari beberapa perusahaan, maka ditemukan adanya kesesuaian pada kompleksitas aktivitas logistik dari beberapa perusahaan dan derajat penyertaan perusahaan jasa logistik pihak ketiga (3PL-third party logistics) dalam melakukan aktivitas tersebut.

\section{Kompleksitas Aktivitas Logistik Perusahaan Pelanggan}

Berdasarkan analisis yang telah dilakukan, terdapat perbedaan tingkat kompleksitas kegiatan logistik pada beberapa perusahaan. Sebagian dari perusahaan pelanggan memiliki aktivitas yang sederhana dan sebagian lagi memiliki aktivitas logistik yang kompleks. Perusahaan-perusahaan tersebut dapat dikelompokkan menjadi 3 kelompok. Kelompok pertama merupakan kelompok perusahaan yang memiliki tingkat kompleksitas tertinggi seperti BP Indonesia, EAC Chemical, Philips Electronics, Eon Chemical, Merck Indonesia, Bristoll Myer, VGI Indonesia, dan SOHO Group. Sementara itu, perusahaan yang memiliki tingkat kompleksitas aktivitas logistik menengah, antara lain Fuchs Indonesia, Charoen Pokphan, Frisian Flag, Nutrifood, Toyota Astra Motor, Daimler Chrysler, ADR Group, Johnson Mathey Ceramics, Grundfos dan Yasulor Indonesia. Perusahaan yang tergolong memiliki tingkat kompleksitas aktivitas logistik terendah misalnya MMC Metal, Wings, Coca Cola Amatil, Martina Berto, Tempo Scan Pacific, Lion Superindo, Pratama Abadi, Intirub, Melapi Timer, Batin Eka Perkasa, Mayor Indah, dan Kageo Igar Jaya.

\section{Derajat Penyertaan Perusahaan Penyedia Jasa Logistik (3PL)}

Berdasarkan derajat penyertaan perusahaan penyedia jasa logistik (Third Party Logistics-3PL) dalam operasi logistik, perusahaan-perusahaan dapat dibagi menjadi 2 kelompok. Kelompok pertama disebut sebagai partly 3PL minor, atau didefinisikan sebagai perusahaan yang secara parsial menyerahkan penanganan logistiknya pada perusahaan jasa logistik untuk sejumlah kecil aktivitasnya. Perusahaan-perusahaan yang tergolong pada kelompok ini antara lain Mayora Indah, Pratama Abadi, SOHO Group, BP Indonesia, Martina Berto, EAC Chemical, Eon Chemical, MMC Metal, Batin Eka Perkasa, Melapi Timber, Kageo Igar Jaya, lion Superindo, Bristoll Myer, Grundfos, Wings, Tempo Scan Pacific, Fuchs Indonesia, Yasulor Indonesia, Intirub, VGI Indonesia, dan Merck Indonesia.

Sedangkan kelompok kedua disebut sebagai partly 3PL major, didefinisikan sebagai perusahaan yang secara parsial menyerahkan penanganan logistiknya pada perusahaan jasa logistik untuk sejumlah besar aktivitasnya. Perusahaan-perusahaan yang tergolong dalam kelompok ini antara lain ADR Group, Daimler Chrysler, Nutrifood, Frisian Flag, Toyota Astra Motor, Johnson Mathey Ceramics, Philips Electronics, dan Charoen Pokphand. Selain kedua kelompok tersebut, sebenarnya dimungkinkan adanya kelompok ketiga, yang disebut sebagai totally 3PL, yang didefinisikan sebagai perusahaan yang menyerahkan aktivitas logistiknya secara total kepada perusahaan jasa logistiknya. Namun, dalam kenyataannya kebutuhan perusahaan terhadap jasa total logistik tersebut sangat terbatas atau bahkan belum ada. 


\section{Segmen Perusahaan Pelanggan Berhubungan dengan Industri Logistik}

Untuk memperoleh segmentasi dari perusahaan-perusahaan pelanggan tersebut, dilakukan pemetaan perusahaan-perusahaan menurut derajat kompleksitas aktivitas logistik dan derajat penyertaan perusahaan jasa logistik dalam melakukan aktivitas logistiknya. Sumbu vertikal mewakili derajat kompleksitas aktivitas logistik yang ada di perusahaan-perusahaan pelanggan, di mana semakin ke atas, semakin tinggi pula derajat kompleksitasnya. Sedangkan sumbu horisontal mewakili derajat penyertaan perusahaan jasa logistik (sebagai pihak ketiga) dalam melakukan aktivitas logistiknya, di mana semakin ke kanan semakin tinggi pula peran pihak ketiga dalam melakukan aktivitas logistik perusahaan.

Dari diagram pada halaman berikut dapat terlihat bahwa terdapat tiga segmen perusahaan. Segmen 1 adalah kelompok perusahaan yang memiliki tingkat kompleksitas aktivitas logistik yang tinggi (kompleks) dengan derajat penggunaan perusahaan jasa logistik yang minim atau minor. Dalam segmen ini terdapat perusahaan-perusahaan seperti EAC Chemical, Eon Chemical, Philips Electronics, Bristoll Myer, Merck Indonesia, VGI Indonesia, dan SOHO Group.

Segmen 2 terdiri dari perusahaan-perusahaan yang memiliki tingkat kompleksitas aktivitas logistik menengah dengan derajat penggunaan perusahaan jasa logistik yang besar. Charoen Pokphan, Frisian flag, Nugrifood, Toyota Astra Motor, Daimler Chrysler, ADR Group dan Johnson Mathey Ceramics adalah perusahaan-perusahaan yang termasuk dalam segmen 2. Sedangkan segmen 3 adalah kelompok perusahaan yang memiliki tingkat kompleksitas aktivitas logistik yang rendah (sederhana) dengan derajat penggunaan perusahaan jasa logistik yang rendah. Yang termasuk dalam kelompok ini adalah perusahaan MMC Metal, Martina Berto, Wings, Coca Cola Amatil, Tempo Scan Pacific, Lion Superindo, Pratama Abadi, Yasulor Indonesia, Intirub, Melapi Timber, Batin Eka Perkasa, Mayora Indah dan Kageo Igar Jaya.

\section{Industri Perusahaan Pelanggan}

Dari segmen perusahaan yang terbentuk, terlihat bahwa perusahaan yang berada pada industri yang serupa cenderung berada pada segmen yang sama. Misalnya, Eon Chemical dan EAC Chemical yang merupakan industri kimia, mereka berada di kelompok perusahaan dengan tingkat kompleksitas yang tinggi dengan derajat penyertaan 3PL yang rendah (segmen 1). Selain industri kimia, pada segmen ini juga terdapat industri farmasi dan elektronik. Sedangkan pada segmen 2 yang memiliki tingkat kompleksitas menengah dengan derajat penyertaan 3PL yang tinggi, terdiri dari industri otomotif, makanan dan minuman, pakan ternak, keramik dan perkebunan. Pada segmen 3, yaitu pada kelompok perusahaan yang memiliki tingkat kompleksitas aktivitas logistik yang rendah (sederhana) dengan derajat penyertaan 3PL yang rendah terdapat industri kosmetika, retail, garment, consumer goods, garmen, barang plastik, sepatu dan manufaktur logam

\section{Atribut penting pemilihan 3PL}

Menurut pandangan perusahaan-perusahaan, harga merupakan atribut penting, dimana terungkap $75 \%$ perusahaan pelanggan menyatakan bahwa harga adalah hal yang mereka pertimbangkan dalam memilih perusahaan jasa logistik. Dari survei juga ditemukan bahwa ketepatan waktu pengiriman (on time delivery), reputasi dan kualitas pelayanan merupakan atribut-atribut penting yang menjadi pertimbangan pemilihan 3PL (diungkapkan oleh 32\% - 40\% perusahaan). Atribut lain yang diungkapkan oleh perusahaan pelanggan adalah kapasitas penanganan, cakupan area pelayanan, keamanan, jumlah armada, pengalaman (track record), kualitas SDM dan kehandalan teknologi informasi yang mereka miliki (10\% - 20\%). Fasilitas, kondisi keuangan, standar keamanan, kecepatan respon, komunikasi, pengalaman khusus pada industri tertentu, jaringan (network), kehandalan (reliability), cakupan servis dan asuransi merupakan atribut-atribut yang jarang diungkapkan oleh perusahaan pelanggan. 
Dari survei terungkap pula adanya perbedaan tingkat kepentingan atribut untuk tiap-tiap segmen perusahaan pelanggan. Pada segmen 1, secara berurutan atribut harga, ketepatan waktu (on time delivery), reputasi, cakupan wilayah servis, dan jumlah armada merupakan atribut penting yang menjadi pertimbangan pemilihan 3PL (berdasarkan frekuensi munculnya atribut tersebut dari survei). Segmen 2, atribut harga, kualitas pelayanan, ketepatan waktu (on time delivery), pengalaman (track record) dan reputasi, secara berurutan merupakan atribut-atrbut terpenting dalam segmen ini. Sedangkan pada segmen 3, atribut harga, reputasi, ketepatan waktu (on time delivery) dan kualitas pelayanan merupakan atribut-atribut penting pemilihan 3PL pada segmen ini.

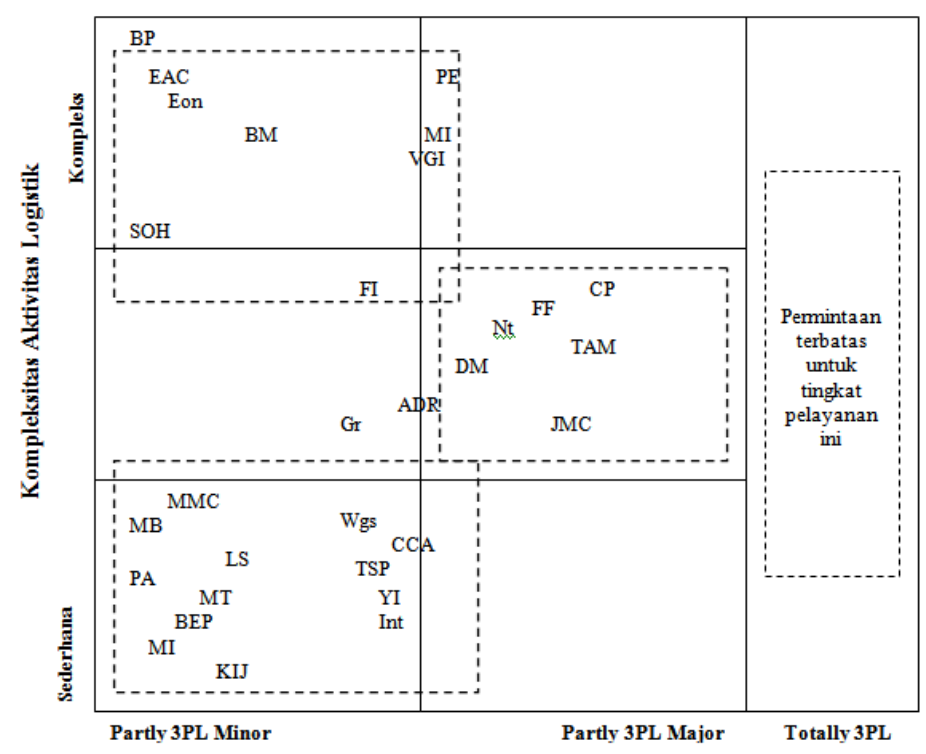

Gambar 4 Derajat Penyertaan Perusahaan 3PL

\begin{tabular}{|c|c|c|c|}
\hline \multicolumn{4}{|l|}{ Ket: } \\
\hline BP & : BP Indonesia & $\mathrm{MMC}$ & : MMC Metal \\
\hline EAC & : EAC Chemical & MB & : Martina Berto \\
\hline Eon & : Eon Chemical & Wgs & : Wings \\
\hline BM & : Bristoll Myer & CCA & : Coca Cola Amatil \\
\hline $\mathrm{SOH}$ & : SOHO Group & LS & : Lion Superindo \\
\hline PE & : Philips Electronics & PA & : Pratama Abadi \\
\hline MI & : Merck Indonesia & TSP & : Tempo Scan Pacific \\
\hline VGI & : VGI Indonesia & YI & : Yasulor Indonesia \\
\hline FI & : Fuchs Indonesia & Int & : Intirub \\
\hline $\mathrm{CP}$ & : Charoen Pokphan & PA & : Pratama Abadi \\
\hline FF & : Frisian Flag & MT & : Melapi Timber \\
\hline $\mathrm{Nt}$ & : Nutrifood & BEP & : Batin Eka Perkasa \\
\hline TAM & : Toyota Astra Motor & MI & : Mayora Indah \\
\hline DM & : Daimler Chrysler & KGI & : Kageo Igar Jaya \\
\hline JMC & : Johnson Mathey Ceramics & & \\
\hline ADR & : ADR Group & & \\
\hline $\mathrm{Gr}$ & : Grundfos & & \\
\hline
\end{tabular}

\section{Atribut Penting versus Keunggulan Bersaing Perusahaan Jasa Logistik}

Keunggulan bersaing yang dimiliki perusahaan-perusahaan logistik akan menjadi berarti bila keunggulan bersaing tersebut dinilai penting oleh perusahaan pelanggan. Dari uraian pada analisis pemain dan persaingan dan uraian mengenai atribut penting pemilihan perusahaan jasa logistik diperoleh keunggulan bersaing untuk masing-masing kelompok perusahaan pesaing yang dinilai 
penting oleh perusahaan pelanggan. Reputasi perusahaan dan kualitas servis merupakan keunggulan bersaing yang mempunyai nilai strategis karena dinilai penting oleh perusahaan pelanggan. Dari sini pula terlihat bahwa setiap kelompok pesaing melengkapi dirinya dengan keunggulan-keunggulan bersaing lain yang dapat membentuk kedua keunggulan bersaing tadi.

Perusahaan logistik kelompok 1 misalnya, mereka membangun reputasi atau nama perusahaan mereka dengan membangun keunggulan bersaing lain, yaitu kualitas sumber daya manusia yang tinggi dan penerapan teknologi IT yang handal. Sedangkan perusahaan logistik kelompok 2 membangun reputasinya dengan menawarkan kualitas pelayanan yang baik yang didukung oleh adanya sumber daya manusia perusahaan yang berkualitas dan penerapan teknologi/IT. Perusahaan logistik kelompok 3 menganggap harga yang kompetitif adalah keunggulan kompetitif yang dapat membangun persepsi perusahaan pelanggan terhadap kualitas servis, selain juga untuk membangun reputasi/nama perusahaan. Perusahaan logistik kelompok 4, seperti halnya kelompok 3 juga menganggap harga yang kompetitif dapat menciptakan persepsi pelanggannya terhadap kualitas servis dan reputasi perusahaan. Selain harga yang kompetitif, kepemilikan sejumlah armada juga merupakan cara mereka membangun persepsi pelanggan terhadap kualitas servis yang mereka tawarkan.

\section{Ukuran dan Pertumbuhan Segmen}

Nilai produksi dari masing-masing industri adalah ukuran yang digunakan dalam melihat besarnya segmen pasar. Sedangkan untuk pertumbuhan industri digunakan nilai indeks dari tiap-tiap industri. Data mengenai nilai dan indeks produksi tersebut bersumber dari Badan Pusat Statistik (BPS). Pada segmen pelanggan 1 yang di dalamnya terdapat industri kimia, elektronik dan farmasi, rata-rata nilai produksinya setahun adalah $\mathrm{Rp}$ 2,4 triliun. Industri farmasi merupakan industri yang memberi kontribusi terbesar terhadap segmen ini, yaitu mencapai Rp 6 triliun dengan rata-rata pertumbuhan $1 \%$ per tahun. Pada segmen pelanggan 2, di mana terdapat industri otomotif, makanan dan minuman, pakan ternak dan keramik, rata-rata nilai produksi untuk seluruh industri tersebut adalah Rp 9 triliun per tahun dengan rata-rata pertumbuhan sebesar 2,5\% per tahun. Segmen pelanggan 3, yang didalamnya terdapat industri kosmetik, consumer goods, garment, produk plastik, sepatu dan manufaktur logam, rata-rata nilai produksinya per tahun adalah Rp 6 triliun, di mana industri garmen adalah industri dengan nilai produksi tertinggi dalam segmen ini dengan rata-rata pertumbuhan sekitar $1 \%$ per tahun.

Akses segmen terhadap jasa logistik terpadu dapat dilihat dari kesiapan segmen tersebut untuk layanan logistik terpadu di masa datang. Dari survei yang dilakukan terhadap perusahaan-perusahaan pelanggan diperoleh, 46\% dari perusahaan yang termasuk dalam segmen 1 menyatakan bahwa ada kemungkinan bagi mereka untuk menggunakan jasa logistik terpadu di masa depan. Sisanya merasa bahwa perusahaan mereka tidak membutuhkan jasa logistik terpadu, baik saat ini maupun di masa depan. Segmen 2 merupakan segmen yang paling tanggap terhadap adanya kemungkinan menggunakan layanan logistik terpadu dari pihak ketiga (perusahaan jasa logistik). Hanya 17\% saja yang tidak merasa membutuhkan layanan logistik terpadu di masa mendatang. Sekitar $83 \%$ dari perusahaan yang tergolong pada segmen ini mulai mengarah untuk menyerahkan aktivitas logistiknya secara total pada pihak ketiga di masa depan. Sama halnya dengan segmen 1, segmen 3 cenderung belum siap sepenuhnya untuk menyerahkan kebutuhan akan aktivitas logistiknya pada perusahaan jasa logistik. Sekitar 48\% dari perusahaan-perusahaan yang berada di segmen ini melihat adanya kemungkinan untuk menggunakan layanan logistik terpadu.

Menurut survey, terdapat beberapa alasan menyangkut ketidaksiapan perusahaan-perusahaan pelanggan untuk menggunakan layanan logistik terpadu, baik saat ini maupun masa mendatang. Faktor biaya merupakan alasan utama, di mana sekitar $40 \%$ perusahaan yang disurvei mengungkapkan hal tersebut. Sekitar 29\% dari mereka juga mengungkapkan bahwa mereka masih sanggup menangani aktivitas logistiknya sendiri, dan 24\% menyatakan keraguannya terhadap layanan jenis ini. Ada juga 
beberapa responden yang mengungkapkan bahwa menyerahkan aktivitas logistik secara total kepada pihak ketiga tidak sesuai dengan strategi perusahaan yang mereka miliki (18,42\%). Beberapa perusahaan juga belum merasa siap untuk menyerahkan kontrol dari aktivitas logistik mereka pada pihak ketiga (15,8\%). Mereka masih ingin memiliki kontrol sepenuhnya (full control) terhadap aktivitas tersebut. Berikut ini adalah alasan yang diungkapkan oleh perusahaan-perusahaan pelanggan, menyangkut ketidaksiapan mereka untuk menggunakan jasa logistik terpadu.

\section{SIMPULAN}

Segmentasi pasar perusahaan jasa logistik dapat didasarkan pada kompleksitas aktivitas logistiknya, yaitu tinggi, sedang atau rendah dan derajat penyertaan perusahaannya, yaitu minor (partly TPL Minor), major (partly TPL Major), dan integrated atau total. Perusahaan-perusahaan pelanggan penyedia jasa logistik dalam industri yang berbeda dapat mempunyai keperluan jasa logistik yang sama dan perusahaan-perusahaan pelanggan dalam industri yang sama dapat mempunyai keperluan jasa logistik yang berbeda. Menyangkut atribut-atribut pilihan terhadap TPL, maka faktor harga yang kompetitif, kualitas servis, dan reputasi perusahaan merupakan atribut-atribut utama yang menjadi pertimbangan pemilihan perusahaan jasa logistik. Perusahaan-perusahaan pelanggan penyedia jasa logistik yang penanganan produknya tergolong semi kompleks merupakan segmen pelanggan yang paling menarik untuk dipenetrasi. Industri-industri yang tergolong ke dalam segmen ini adalah otomotif, makanan dan minuman, pakan ternak, keramik, dan perkebunan.

\section{DAFTAR PUSTAKA}

Alsem, K.J. (2007). Strategic marketing: An applied perspective, New York: McGraw-Hill/Irwin.

Best, R.J. (2004). Market-based management: Strategies for growing customer value and profitability, $3^{\text {rd }}$ ed., New Jersey: Pearson Education.

Bowersox, D.J., Closs, D.J., and Cooper, M.B. (2002). Supply chain logistics management, New York: McGraw-Hill/Irwin.

Business Plan Team. (2004). Business plan, PT Silkargo Indonesia 2004-2008.

Cravens, D.W., and Piercy, N.F. (2009). Strategic marketing, $9^{\text {th }}$ ed., New York: McGraw-Hill/Irwin.

Hooley, G., Piercy, N.F., and Nicoulaud, B. (2008). Markting strategy and competitive positioning, $4^{\text {th }}$ ed., England: Pearson Education Limited.

Hopp, W.J. (2008). Supply chain science, New York: McGraw-Hill/Irwin.

Simchi-Levi, D., Kaminsky, P, and Simchi-Levi, E. (2004). Managing the supply chain: The definitive guide for the business professional, New York: McGraw-Hill.

Stock, J.R., and Lambert, D.M. (2001). Strategic logistics management, $4^{\text {th }}$ ed., New York: McGrawHill.

Walker, O.C., Boyd, H., Mullins, J.W. (2005). Marketing strategy: A decision-focused approach, $5^{\text {th }}$ ed., New York: McGraw-Hill/Irwin. 